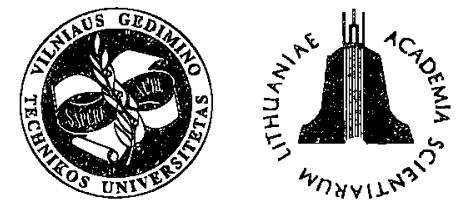

ISSN 1648-4142 TRANSPORT

http:/www.vtu.lt/english/editions

TRANSPORT - 2003, Vol XVIII, No 6, 248-254

\title{
MULTIMODAL APPROACH TO THE INTERNATIONAL TRANSIT TRANSPORT*
}

\author{
Darius Bazaras ${ }^{1}$, Ramūnas Palšaitis ${ }^{2}$ \\ Dept of Transport Management, Vilnius Gediminas Technical University, \\ Plytines g.27,LT-2016 Vilinius, Lithuania.Tel.:2744776. ${ }^{1}$ E-mail: dbazaras@one.lt; ${ }^{2}$ E-mail: trvadyba@ti.vtu.lt
}

Received 200306 09; accepted 20031114

\begin{abstract}
In the article not only the problems of multi-modal and inter-modal conveyances in Lithuania and the concept of transit and the transit system stimulating factors are analysed, but also the modelling of transit transport and the flows of the loads are given. The main part of the article comes to the analysis of resent situation of Lithuania. In this part the place of transport sector in the market of transit services is analysed and the transit profit for Lithuanian economy is evaluated. The conclusions and proposals are given at the end of the article.
\end{abstract}

Keywords: transport, transit, transport types, loads, conveyances, terminals, logistics.

\section{Introduction}

Lithuania has a comparatively well developed transport system, convenient geopolitical situation and fairly well developed transport infrastructure. These factors allow Lithuania to tune to the changes of the transit services market and to appear as the mediator expanding dealing (using the main corridors of transport) between East and West.

It is evident, that if certain projects of transit services market development and modernisation are not implemented, and modern technologies are not introduced, it will be impossible to compete with similar services providers on an international level. The potential income of the state, work and the possibilities of rapid integration into the European Unions economical space will be lost as well. That is why the development of the transit transport services must become one of the underlying goals of Lithuanian economic policy.

\section{The Analysis of Non-fiction}

In the world the transit loads transport is not much researched as the object of integral scientific inquiry. Consequently the analysis of special factors and processes, which influence this interaction, is very important and namely the synthesis of the research mentioned above ensures the proper base for it.

The problem of interaction has been researched for a few decades. However its object has not been clearly

*) Discussion of the results of the programme „Transport: technologies, economic, environment, health. defined yet and the process of conceptualization lasts till now. Revicwing the history of the development of joint transport, G. Muller [1] stressed, that the beginning of this conception guides to the practice of business, while the transport economists and the authors of science of the logistics had endued the background for this process at a later date.

Regarding the fundamentals of transport modelling, the transit transport started to be analysed taking into account the external forces of micro and macromedia.

The interaction of different micro-medias descriptions is being studied considering the question in all its aspects, normally - from the positions of microeconomics. Looking at the question from the angle of transport management and transit strategies, the main points are tightly related to the screening of transporters and transport kinds [2-3], information technologies [4-5] as well as management and administration [6-7]. The finances (transport expenses, valuing, etc.) and the profitability of enterprises activities [8] can be separated as a special bloc.

However, the authors (mentioned above) have not spared enough attention for the joint transit transport development, which would be related to contemporary decisions of logistics. It is evident, that there is a lack of attention for the analysis of the conception of joint transport as well. Furthermore, ignoring the peculiarity of transport descriptions, the joint transit transport is analysed as a whole. It means that such a slight analysis does not allow to make the circumstantial conclusions and to reach optimal results at the end [9].

It is evident that the state or region transport infrastructure is used in the most effective way when the stra- 
tegic model of transit transport flows is generated orienting towards the minimal expenses [10-12]. Even if the assumption (concerning the existence of circumstances which does not allow transporting the loads on schedule without high expenses) is justified, it holds true, when the operational model is shaped towards the minimising of common expenses.

Stressing the impact of time and the expenses on the loads transport, scientists have conceived that these elements are influenced by the connection between the headway and the time of the load conveyance. These agents show that transport services, being the constituent of marketing and logistics systems, create the purpose of time and place as well as form and disposal [12].

It is necessary to stress that the tendency to separate forces which are related to client services (pace, pliancy, accessibility), organisational needs (scope of the orders, rate) and loads internal (quantity, weight, packing), is heightening. This prompts to apply the marketing theory for the joint loads transport process. Such a decision would create the best possibilities to meet the requirements of clients.

The services of transit loads flows would create the possibility to increase the scope of Lithuanian transport enterprises services and would originate the demand in the market of trade and services. However, seeking to realise the objectives of business inducement, it is necessary to create the environment, which would be attractive for its technical, technological, organisational and legal elements. This environment must secure the trusty and safe services for transport flows as well.

For this reason the Lithuanian transport system must be reorganised - both its technical situation and its legislation must become acceptable for natural persons and legal bodies which are involved in the activities of loads transit.

Since the industrial potential of high technically developed but insufficient of natural resources Western countries exceeds the demands of their local markets and the perspectives of the fast development of CIS and other Eastern countries, which are affluent of unexploited natural resources, markets are evident, Lithuania could take the position of "the third logistics country" between them.

\section{Modelling of the Transit Transport and the Flows of Loads}

In the analysis of inter-state flows of transport [1314] it is hypothesised that the joint flows of goods and the values of economical variables are related according to the formula introduced below:

$$
Q_{K}^{O D}=f\left(P_{K}^{O D}, \tilde{P}_{K}^{O D}, I^{D}, D_{m}\right),
$$

here: $Q_{K}^{O D}$ is the quantity of goods $K$, which were made in $O$ country and sent to country $D$;
$P_{K}^{O D}$ is the price after the goods are delivered to country $D$ (the production expenses plus taxes for the transportation);

$\tilde{P}_{K}^{O D}$ is the price of goods $K$, which were delivered to country $D$, if $\mathrm{K}$ had been bought some where (not in country $O$ );

$I^{D}$ is $D$ countries;

$D_{m}(m=\ldots M)$ is a range of possible variables, which show the unvalued characteristics of production and consumption in the analysed countries.

Here it is proposed that the delicacy of inter-state flows of goods can be estimated evaluating all competitive factors. These flows can be influenced by the factors from a supplying side (ex. production expenses in provenance country, the expenses of transportation from the provenance country $O$ to the located place $D$, etc.) and the factors from a demanding side (income in the located country $D$, the prices of the alternatives, which can be purchased in the competitive country, for goods $K$, etc.). If all other factors are invariable, it is expected, that:

- the increase of the price (after $P_{K}^{O D}$ is delivered) will reduce inter-state flows from the provenance country $O$ to the located place $D$;

- the increase of the price $\widetilde{P}_{K}^{O D}$ of alternative goods will increase inter-state flows from $O$ to $D$; and the increased income $I^{D}$ in the located place will increase inter-state flows from $O$ to $D$ as well.

The importance of this model consists of several things:

- It is essential to test if the results of calculations satisfy the theoretical expectations;

- It is essential to test what are the degrees of impact. Testing the degrees of impact it is possible to invoke the delicacy analysis which allows estimating:

- if increasing expenses of transportation reduces the flows of goods;

- how the flows of goods are influenced by the income changes in the countries analysed.

The answers to these questions and the questions concerning the quantitative impacts of variables, are very important, because of their influence on inter-state relations development and their power to determine both the scope of transit transport in the intermediate countries and the scale of influence of national transport enterprises in the market.

The data concerning inter-state transportation can be taken from the statistics of the loads/goods conveyance. The expenses of goods production can be found in the same way, but this information must be taken by their producers.

In accordance with the results of the analysis of inter-regional conveyance of the goods [13-14] the main formula for the evaluation of effectiveness of the process is: 


$$
Q_{K}^{O D}=\alpha_{0}+\alpha_{1} P_{K}^{O D}+\alpha_{2} \widetilde{P}_{K}^{O D}+\alpha_{3} I^{D}+\sum_{m} \alpha_{m} D_{m}+\varepsilon
$$

its variables are explained above and a is the bias of the term.

Making the analysis of every couple of provenancelocation place, the production expenses were calculated dividing the overall price of the transported loads by their overall tonnage. The real price of the goods (after they were delivered from the provenance place $O$ to the located place $D$ ) could be calculated adding the index of conveyance expenses and dividing the result by the index of wholesale prices (taking into account the situation in a different year).

The real income of the state can be calculated like for every single resident falling income after the deflation regarding the national index of consumption prices.

On the contrary to the economical theory which states that prices of related alternatives are the important determinants of inter-state flows the analysis does not show that such an impact is considerable. That is why the variables were deleted from the presented model. These empirical data do not show, that the prices of alternatives are not economically important, but that the prices of alternatives were not very different in separate countries. This proves the consistent pattern that in the case of huge regional grossing, the production activities are divided gradually in the regions.

During the analysis it was also found that the conveyance costs do not reduce the inter-state flows of goods much. It depends on the ductility of the flows of loads, on the change of the loads flow increasing the expenses of conveyance, and other factors remaining unalterable.

These results of the ductility show that rather big changes of prices must occur after delivery - only they can influence on inter-state flows. Besides, little ductility of conveyance prises shows that inter-state flows of the goods are usually insusceptible for the expenses of the conveyance. Despite this, it is important to take into account, that the more market is competitive, the more ductility of the flows of goods is vis-à-vis bigger the expenses of the conveyance. It is evident, that the income plays an important role, therefore the conclusion, that rapid economical development of separate countries has a bigger impact on inter-state flows of the goods, can be made.

\section{Current Situation of Transit Transport in Lithuania}

Transit is grasped as the transportation of goods via third countries. Consequently it could be the background, the objective and the measure for the development as well as the indicator of the development rate, the object of scientific research, the sphere of planning logistics and cooperation.

The main problem of the transit transport is the in- fusion of the flows of transit loads.

It is known that various vehicles are used for the transportation of transit loads - they cover the whole transport system. Therefore, seeking to improve the transit process, it is necessary to identify all positive and negative factors, taking into account that it is impossible to change the process - it changes in accordance with the changes of the object of our interests - the factors of transit - functional and dysfunctional links as well as contradictive subjections and reasons.

\subsection{The Evaluation of Profit of Transit for Lithuanian Economy}

The transit transport profitable effect for the economy of the state can be evaluated by counting paidin taxes (ex. entry, transit, ecological, using of infrastructure, etc.). The transit states income could consist of the prices of taken services and the goods, which were bought. The ways of getting profit from the transit are offered in the scheme below.

The development of transport increases the mobility. Therefore the bigger part of the consumer goods can be distributed among the consumers. The transport system of more developed countries creates from 4 to $8 \%$ of gross national product and gives from 2 to $4 \%$ of workplaces.

The effectiveness of the countries transport system can be evaluated calculating both the common socio-economical profit and the negative impact which is determined by the separate parts or even the whole transport system (see Fig 1).

Recently private businessmen and business companies are interested in the projects and single elements of the alternative transport system as well as their impact on the increasing income of residents creating new workplaces, economical rising of the concrete region, increase of the number of inhabitants and traffics, change of a settlement system, etc. This phenomenon could be assigned to socio-economical effects. It must be taken into account before the adoption of the final strategy of transport system development and the estimations of the scope of investments.

The methodology must be corrected every time when the socio-economical impact of transit is analysed. It must be done in consideration with the specification of the district, town or region being analysed - the territorial location of both socio-productive and culture-domestic objects, the scope of the sphere of production and services, the population, the settlement and other factors must be taken into account.

\subsection{The Place of Lithuanian Transport Sector in the Market of Transit Services}

The flows of loads are the main factors of the transport system functioning. Market determines the flows of 


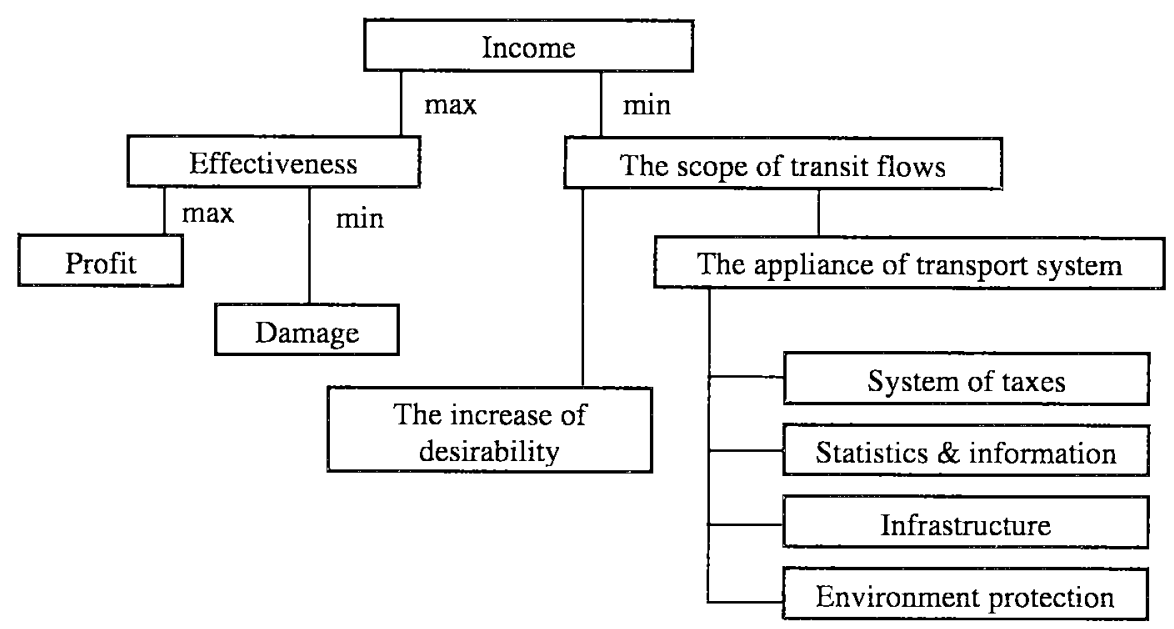

Fig 1. The effectiveness of the countries transport system

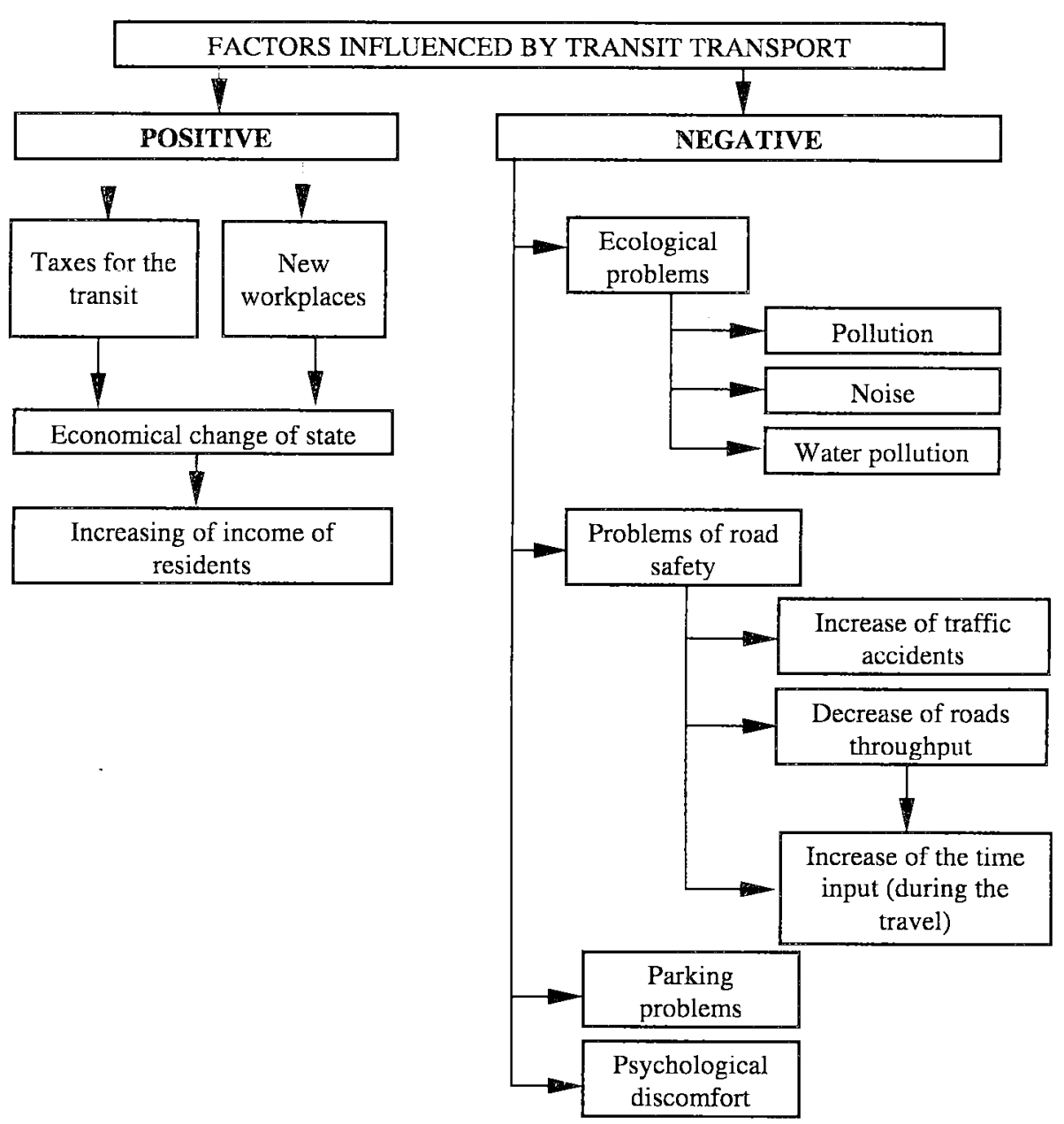

Fig 2. Factors influenced by transit transport

the transport, and their repartition among the corridors of transport - the concrete systems of the transport, and especially - technical, organisational and legal conditions of the transport linkage (Fig 2).

The main transit loads (from East to West and back through the frontier in Kalvarija) are freighted by automobile transportation.

Recently the main transit loads are freighted through the IX corridor in Lithuania. Here huge amounts of loads, which are freighted by trains along the railways between 
Russia (through Byelorussia, Shumsk and Stasylos), Klaipeda (Klaipeda harbour has the terminal for the road/ railroad ferries) and Kaliningrad regions (through Kybartai). In most cases it is the traffic of Russian and other CIS countries export (metalwork, scrap-iron, ironstone, oil products and the nuclear fuel), freighted as transit goods through Lithuania. Lots of export and import loads are freighted by trains for/to Russia, and, in the case of export - to Klaipeda (harbour) region. Lots of import and export loads are freighted by trains through Lithuanian-Latvian frontier in Sarkiai and Laižuva (not far from the Mažeikiai oil recast plant).

Recently in Lithuania the main transporter of the transit loads is SC "Lietuvos geležinkeliai". It is evident, that transit transport has a big impact on the increase of railroads income and the profitability of economical activities. Despite the fall of market at the beginning of the period of regaining the independence (1990-1995), in the period of 1996-1998 the transportation of the loads increased by $6,1 \%$ (from $29,1 \mathrm{~min}$. $t$ to $30,9 \mathrm{mln}$. t). But in 1999, after the changes in foreign countries had occurred, the scope of the transportation services decreased more than $8 \%$. The structure of services notably changed: $53,4 \%$ (in 1999) and $58,6 \%$ (in 2000) of flows were transit (47,3\% in 1998), therefore in 2001 the amount of transit loads was less than in 2000 .

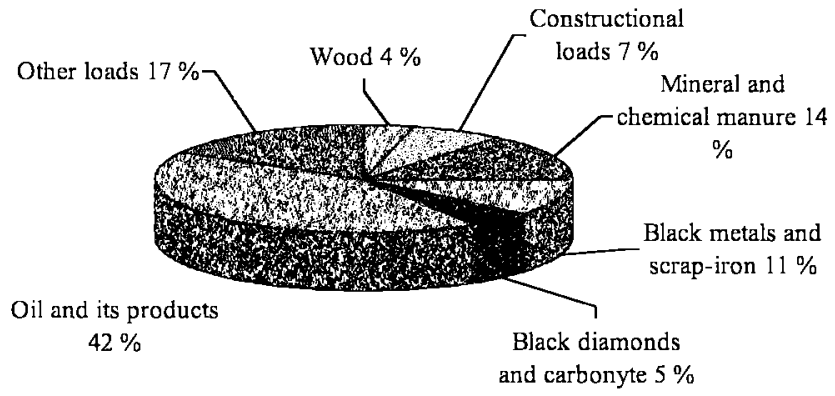

Fig 3. The structure of 2002 railroad conveyed loads
The increase (by 1,6 times) of conveyances to Kaliningrad has the biggest impact on the increase of transit conveyances (in comparison with 2001). In IV quarter of 2002 the scope of the conveyances to Kaliningrad extremely increased - black metals (by 2,3 times), oil products (by 2,7 times) and grains (by 4 times).

In $200210,6 \%$ more (than in 2001) loads were transported to Klaipeda. The scope of transportation of oil products has the biggest impact on this growth. The conveyance of other products (by trains, through the harbour of Klaipeda) decreased by $7,0 \%$ in 2002 (in comparison with 2001).

In $20023,1 \%$ more loads (in comparison with 2001) were transported driving to the direction of Poland through Šeštokai.

In 2002 the scopes of the loads (transported through the International ferry Klaipeda-Mukranas) have reduced by 3 times. Seeking to increase the scope of loads transport, SC „Lietuvos geležinkeliai" negotiates with Germany regarding putting in to practise (from the $1^{\text {st }}$ of July, 2003, transporting the loads through Mukran) CIM (the rules of international conveyance of loads) these rules are held all over Europe).

Oil and its products have got the biggest part of the loads market $(42,1 \%)$. Chemical and mineral manure has got $14,3 \%$, while black metals and scrap-iron - $10,6 \%$. Degrees of their conveyance have increased pro rata $39,5 \%, 16,9 \%$ and $23,5 \%$ in 2002. Constructional loads have got $7 \%$ and wood $-4 \%$ (see the Fig 3) in 2002 . The income from loads transport increased by $27,8 \%$ (in comparison with 2001).

On the contrary to railroad transport, which is still a monopoly, the transport of automobiles is very decentralised.

During 2002 Lithuanian road transporters used 447 thousands of licenses for international conveyance of loads. It makes $12 \%$ more than during 2001. In 2002 transit transports through Lithuania by the road transport had increased (in comparison with 2001) by $19,8 \%$

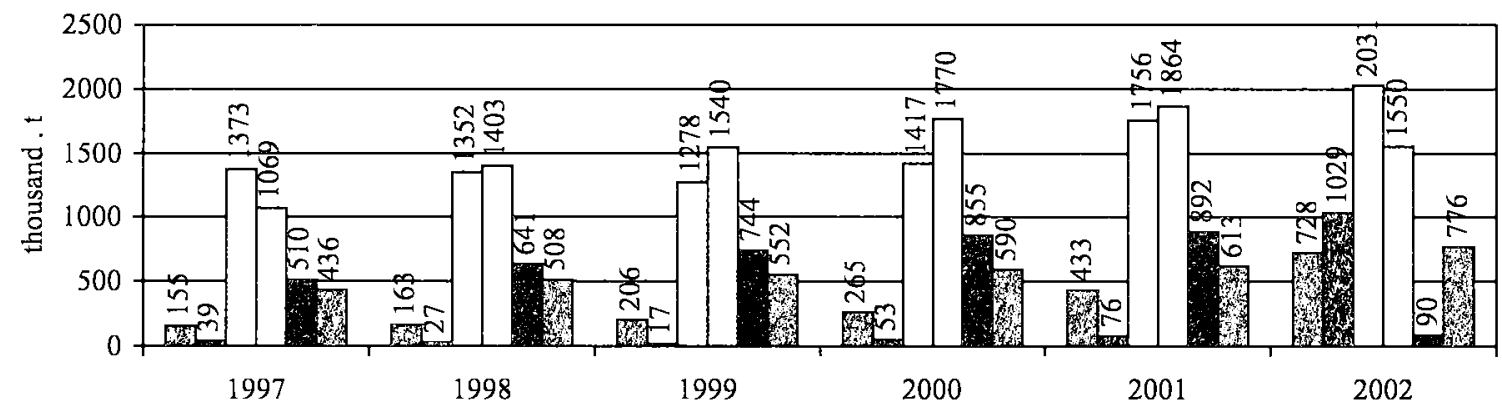

Poland Estonia $\square$ Latvia $\square$ Russia Ukraine Belorus

Fig 4. Foreign Ioads transit (by road transport) through the territory of Lithuania 
and spread: $17,7 \%$ - to Klaipeda harbour, $11.6 \%$ - to Kaliningrad, to highway „Via Baltica“ $-60.4 \%$. In 2002 the conveyances of export and import increased (in comparison with 2001): export- $12.3 \%$, and import- $25,2 \%$. In $2002,42,3 \mathrm{mln}$. $\mathrm{t}$ of loads were transported by road transport - it is $6,2 \%$ less than in 2001 . The local conveyances had made $85 \%$ of all road conveyances and the in scope decreased by $10 \%$. The international conveyances by road transport have increased by $22 \%$.

In comparison with railroad transport the transit conveyances by road transport are less. Despite big difference (see Tables 1 and 2) it changes in behalf of road transport.

IXD: Kiev - Minsk - Vilnius - (Kaunas - Garliava - Mauručiai - Puskelniai - Marijampolè - Vilkaviškis Kybartai) - Kaliningrad.

IA: Helsinky - Tallinn - Riga - (Kalviai - Šiauliai - Kryžkalnis - Tauragè - Pagėgiai - Panemunè) Kaliningrad - Gdansk.

IXD: Kiev - Minsk - Vilnius - (Kaišiadorys Palemonas - Kaunas - Kazlụ Rūda - Kybartai) Kaliningrad.

IA: Helsinki - Tallinn - Riga - (Šarkiai - Radviliškis - Pagégiai) - Kaliningrad - Gdansk.

Road transport dominates in I corridor and Via Baltica road while in IX corridor - transit conveyances by trains (Fig 4).

In 2002 19,7 mln. t. of loads were loaded in Klaipèda harbour - it is $14,1 \%$ more than in 2001 and 2,6 \% more than in 2000. It is the biggest result of loading in 12 latter years (the dynamics of loading in Klaipeda harbour is presented in Table 3). In 2001 some companies exceeded the quotas of loading: SC "Klaipedos nafta"

Table 1. The transit of road transport through Crete corridors

\begin{tabular}{|l|l|l|l|l|l|}
\hline & 1998 & 1999 & 2000 & 2001 & 2002 \\
\hline $\begin{array}{l}\text { Whole transport through } \\
\text { Lithuania (thous. t) }\end{array}$ & 3586 & 3815 & 4412 & 4714 & 5646 \\
\hline Via Baltica & 2164 & 2496 & 2920 & 3047 & 3413 \\
\hline IXB & 111 & 53 & 122 & 394 & 565 \\
\hline IA (VIA Hanziatica) & 20 & 17 & 19 & 22 & 19 \\
\hline IXD & 147 & 222 & 375 & 401 & 470 \\
\hline
\end{tabular}

Table 2. The transit of railroad transport through Crete corridors

\begin{tabular}{|l|l|l|l|l|l|}
\hline & 1998 & 1999 & 2000 & 2001 & 2002 \\
\hline $\begin{array}{l}\text { Whole transit through } \\
\text { Lithuania (mln. t) }\end{array}$ & 13,7 & 15,1 & 18,0 & 15,15 & 20,79 \\
\hline IXB & 8,5 & 9,2 & 11,6 & 6,98 & 7,7 \\
\hline IXD & 4,9 & 5,6 & 6,2 & 7,8 & 12,7 \\
\hline IA (thous. t) & 98,1 & 55,1 & 29,2 & 287,8 & 286 \\
\hline I corridor (thous. t) & 46,0 & 28,5 & 37,7 & 52,0 & 53,3 \\
\hline
\end{tabular}

Table 3. Loading and landing of the loads in Klaipeda harbour

\begin{tabular}{|l|l|l|l|l|l|l|}
\hline & 1997 & 1998 & 1999 & 2000 & 2001 & 2002 \\
\hline $\begin{array}{l}\text { Overall } \\
\text { circulation of } \\
\text { harbour (mln.t) }\end{array}$ & 16,13 & 15,00 & 14,97 & 19,24 & 17,297 & 19,74 \\
\hline Covers transit & 10,90 & 9,24 & 9,60 & 12,43 & 7,85 & 8,82 \\
\hline$\%$ & 67,60 & 61,60 & 64,10 & 64,60 & 45,40 & 44,7 \\
\hline $\begin{array}{l}\text { Transfer of } \\
\text { loads (mln. t) }\end{array}$ & 12,44 & 12,22 & 12,26 & 15,49 & 13,079 & 15,18 \\
\hline Covers transit & 8,95 & 7,77 & 8,06 & 10,56 & 6,279 & 7,20 \\
\hline$\%$ & 71,90 & 63,6 & 65,70 & 68,20 & 48,00 & 47,5 \\
\hline $\begin{array}{l}\text { Landed loads } \\
\text { (mln. t) }\end{array}$ & 3,69 & 2,78 & 2,71 & 3,75 & 4,218 & 4,56 \\
\hline Covers transit & 1,98 & 1,47 & 1,54 & 1,87 & 1,571 & 1,62 \\
\hline$\%$ & 53,70 & 52,90 & 56,80 & 49,90 & 37,20 & 35,5 \\
\hline
\end{tabular}

$(+30 \%)$, SC "Klaipedos Smeltè" together with JSC "Biriu kroviniu terminalu" ( $+48 \%)$. The loadings of other companies increased, but not much.

In 2002 Klaipeda harbour (besides oil products) transferred $13,1 \mathrm{mln}$. $\mathrm{t}$ of loads $-0,9 \mathrm{mln}$. t, or $7,4 \%$, more than in 2001. In $20026,68 \mathrm{~min}$. $t$ of oil products were transferred $1,6 \mathrm{mln}$. $\mathrm{t}$ or $30 \%$ more than in 2001 . An increase of the loading of oil products became one of the main causes of Klaipedas harbour loadings increase.

The flows of manure and Ro-Ro loads did not change much, but there is a need to notice the rates of containers and minerals loading: 71,6 thousand TEU (38,6\% more than in 2001) were transferred in 2002. In 2002 more than $1 \mathrm{mln}$. $t$ of minerals were transferred, whereas there were practically none of them in 2001. In 2002130560 units of Ro-Ro devices (loads and road transport devices) were transferred, - it is $3,1 \%$ less than in 2001. In 2002125872 units of road transport devices were transferred, it is a little more than in 2001. A big increase of car loadings $(18,8 \%)$ and a big decrease of trailer loadings $(8,2 \%)$ were detected. Therefore only 4688 units of railway loads were transferred in 2002, it is $53 \%$ less than in 2001 . These factors determined the decrease of Ro-Ro loads.

In 2002 the Lithuanian harbours total by 6502 ships $(6,1 \%$ more than in 2001) were loaded and totally 25,8 mln. $t$ of loads (15,5\% more than in 2001) had been transferred.

Recently the reconstructions (harbour deepening, reconstruction of harbour gates, reconstruction of the railroads and widening of the roads to the harbour, etc.) of Klaipeda harbour are proceeded. In 2002 the amount of bounds repair made $11,37 \mathrm{mln}$. Lt. The total length of the repaired bounds is $1080 \mathrm{~m}$. The main design capabilities of structural elements were restored, the navigation conditions and the safety of loading work became better, after the bounds were repaired. The extension work of northern and southern piers is already done and the 
resent pier is already repaired. The deepening of the mouth is already done too. It is $14 \mathrm{~m}$ deep (sea part $14,5 \mathrm{~m}$ ) now. The harbour got the status of a deep-sea harbour and now even "PANAMAX" ships (with max. $12,5 \mathrm{~m}$. draught) can enter it.

In $20022449 \mathrm{~m}$ of railroads were driven. In 2002 the total amount of $123,8 \mathrm{mln}$. Lt was spent for investment projects.

Resent inter-modal services of Klaipèdas harbour actually limit the conveyance of Russian and other CIS countries unitary loads.

\section{Conclusions and Proposals}

Having analysed and evaluated the resent situation of Lithuanian transport system and its feasibility for the transit and the significance of the transit for Lithuania and its economy, such conclusions and proposals could be made:

1. Transit transport is very significant seeking to increase an income of national budget. Therefore, increasing the scale of trading between East and West, it is necessary to foster the development of transit flows. It can be done using the resent Lithuanian transport infrastructure.

2. Evaluating all the system of transit services, the significant role goes to centres of the logistics, terminals of import and export. Therefore it is possible to think about the necessity to found the net of logistics terminals in the nearest future. It is necessary to improve the technical basis of the resent terminals of logistics as well.

3. Klaipeda harbour does not use enough the possibilities given by the inter-modal transport. Developing the inter-modal and join transport it is very important to improve the interaction between harbour and other types of transport.

4. Developing transit transport it is necessary to apply the multimodal approach. The priority must be given to the development of joint transport infrastructure, technologies and conveyance services in all spheres of transport, and especially in transit attendant transport corridors of international significance. The concerted level of the development of these transport branches (especially see, railway and road transport), the integrity of their markets and the interaction based on the principles of the logistics has the significant influence on the effectiveness of services of a transport sector. Therefore the development and promotion of the services of multimodal transport must become one of the main objectives of Lithuanian transport policy.

\section{References}

1. Muller, G. Intermodalism: 40 Years Young. Transportation Quarterly, No 4, Annversary Issue. Lansdowne: ENO Transportation Foundation, Inc., 1996, p. 87-94.

2. Cheung, Y. H. F.; Blok, P. M. Determining the Prospects for a Shift in Modal Split in Freight Transport. Freight Transport and the Environment. Amsterdam: Elsevier, 1991, p. 226-233.

3. Murphy, P. R.; Daley, J. M. A Preliminary Analysis of the Strategies of International Freight Forwarders. Transportation Journal, No 4. USA: American Society of Transportation and Logistics, 1996, p. 5-11.

4. Martin, J. D. Itermodal Transportation: Evolving Toward the 21 Century. Transportation and Distribution, No 2, 1996, p. 1-11.

5. Crum, M. An Assessment of Motor Carrier Adoption, Use and Satisfaction with EDI. Transportation Journal, No 4, 1996, p. 44-53.

6. Williams, P. Transportation Management. The Distribution Management Handbook. New York: McGraw-Hill, Inc., 1994, p. 24.1-24.21.

7. Kent, J. L.; Flint, D. J. Perspectives on the Evolution of the Logistics Thought. Journal of Business Logistics, No 2, 1997, p. 15-29.

8. Palšaitis, R. The evaluation and regulation of the impact of the transit transport on socio-economical characteristics. Transport Engineering (Transportas), 1997, No 1(14), p. 48.

9. Slater, A. Choise of the Transport Mode. Aldershot: Gower, 1990, p. 314-339.

10. Baublys, A. Politic of Transport (Transporto politika). Vilnius: Technika, 1996. 254 p. ISBN 9986-05-257-2 (in Lithuanian).

11. Šakalys, A.; Lingaitis, P.; Palšaitis, R.; Jurkauskas, A.; Paulauskas, V.; Stankūnas, J.; Jarašünienè, A. Lithuanian transport and transit development strategy (Lietuvos transporto ir tranzito plètros strategija). Vilnius, $2002.29 \mathrm{p}$. (in Lithuanian).

12. Palšaitis, $R$. The problems of transport and logistics development in Lithuania. In: The problems of transport and the ways of their solution. Lithuanian Science Academy reports material. Tranzito ir logistikos pletros problemos Lietuvoje. Iš: Transporto problemos ir jų sprendimo būdai. Lietuvos mokslų akademijos sesijos pranešimų medžiaga, Vilnius, 2000 m. gegužès 23 d.). Vilnius, 2000, p. 118-129 (in Lithuanian).

13. Burkovskis, R. Impact of internal and external factors on rail - port interface. Summary of Doctoral Dissertation. Vilnius: Technika, 2002. $36 \mathrm{p}$.

14. Burkovskis, R.; Palšaitis, R. The interaction of Klaipedda harbour and railroads Klaipèdos jūrų uosto ir geležinkelio sąveika. Transport, Vol XVII, No 2, Vilnius: Technika, 2002, p. 71-75. 